\title{
Intercellular Bridges Present
}

National Cancer Institute

\section{Source}

National Cancer Institute. Intercellular Bridges Present. NCI Thesaurus. Code C136715.

A microscopic finding indicating the presence of intercellular bridges connecting adjacent cells in a tissue sample. 